\title{
Analysis of Factors Contributing to Time Overruns on Road Construction Projects under Addis Ababa City Administration
}

\author{
Siraw Yenesew Tesfa \\ Department of Management, College of Business and Economics, ADDIS ABABA University, Ethiopia
}

\begin{abstract}
It is well known that most road construction projects in Ethiopia and Addis Ababa city are exposed to time and cost overrun or both. It becomes difficult to complete road projects in the allocated cost and time. Therefore, this research was carried out to dig-out information on the factors that cause time overrun on Asphalt road construction projects in Addis Ababa City administration. Questionnaire survey was used to collect data on causes of time overrun. A total of 47 questionnaires from owner (AACRA), contractors and consultants were collected on the common factors to contribute for time overrun on asphalt road construction projects completed from 2000-2005E.c in Addis Ababa city administration by using a purposive sampling technique and analyzed using both descriptive and inferential statistics. Secondary data (asphalt road construction projects completion report) was used to know the real extent of time overrun on the projects understudied. From the result, it was found that $80 \%$ of the projects suffered time overrun. The most important causes of time overrun were found to be slow cite clearance, contractors' financial problems, Inflation, progress payments delay by owner, inaccurate cost estimation, and delay in commencement. Spearman rank order correlation analysis was used to evaluate whether consensus of views exists between groups of respondents (owner versus contractor, owner versus consultant and contractor versus consultant). From the analysis of the results, it was found that there is no consensus of opinion between owner versus contractor and owner versus consultant respondents on the factors that cause time overrun but there is consensus between contract and consultant respondents. Lack of adequate literatures' on my case study was the limitation of this study.
\end{abstract}

Keywords: time overrun, causes, factors, asphalt road construction projects, Road construction project stake holders

\section{Introduction}

\subsection{Background of the Study}

Project management is the application of knowledge, skills, tools and techniques to project activities to meet project requirements (PMBK 2000 Ed.). Ibrahim Mohamed, Hail University, (2013), indicated that time, cost and quality have their proven importance as a prime measures for project success. As it is prevailed above project requirements are commonly assumed to be time, quality and cost of a project. Success and failure of any project will be measured by these three requirements.

The construction sector particularly road construction is a very important sector for the development and economic growth of any developing country (M.Haseeb, 2011). Ethiopia and/or Addis Ababa city is under development and the development of road construction is vital like any other developing country if not more vital.

In Ethiopia, particularly in Addis Ababa, there are many road projects constructed, under construction and planned to be constructed. But, a very common problem which is affecting almost all road construction projects in the city is the failure to meet the stated/planned completion period (delay).

And therefore, this chronic problem is repeatedly happening in almost all road projects of Addis Ababa city administration and we can assume list of factors to affect the on time accomplishment of projects. This research aims at identifying the most common and frequent factors which contributes for this problem (time overrun)

\subsection{Statement of the Problem}

This section of the research states about the motivations (deriving force) to study the selected area. The initiation for the study of this research is largely due to personal observation and low performance of asphalt road construction projects in Addis Ababa city administration in terms of time (delay).

According to Majid (2006), a construction project is commonly acknowledged as successful when it is completed on time, within budget, in accordance with specifications, and to

Most construction projects in this country (Ethiopia) suffer time and cost overrun, (Fetene Nega, AAU, 2008). As it is obviously known, Addis Ababa is the capital city of both Ethiopia and Africa and this fact makes the necessity of standardized roads in the city even more critical and vital. Despite the fact that Efforts of the city administration are visible, construction delay remains the main problem and there are various factors which affect the accomplishment of projects as planned in our case in terms of time requirement.

The factors could be various in numbers and types in different situations, countries and circumstances. Various studies have been conducted to identify the most critical, common and frequent factors as a cause of time overrun in different countries and situations.

According to M.Haseeb, et al., (2011), the most important and highly ranked delay causes in construction industry of Pakistan is inaccurate time estimation. But in another study, 


\section{International Journal of Science and Research (IJSR) \\ ISSN (Online): 2319-7064}

Index Copernicus Value (2013): 6.14 | Impact Factor (2015): 6.391

Mahamid (2013), the most important and highly frequent Couse of delay is financial status of the contractor.

Therefore, from the above fact, we can ascertain that important and frequent factors for project delay could be different in different situations. Generally, this study tried to identify the most common and frequent factors of delay for road construction projects in Addis Ababa city administration.

\subsection{Objectives of the Research}

\section{General objective}

The general objective of this study was to identify the most common and frequent factors of delay (time overrun) in road construction projects of Addis Ababa city administration.

\section{Specific objectives}

This study has been undertaken with the following specific objectives

1) To identify factors contributing for time overrun on asphalt road construction projects under AACRA and evaluate their relative importance and frequency of happening

2) Investigate the views of different construction parties (owner, contractor and consultant) to rank the identified factors based on their commonness and frequency.

3) To evaluate the degree of agreement /disagreement regarding the ranking of these factors between the construction parties.

4) Identifying the extent of time over run for various road construction projects under Addis Ababa city administration

5) Forwarding recommendations to minimize or to avoid time overrun and frequency of its occurrence; and hence to reduce its consequential effects on road construction projects in Addis Ababa city administration.

\section{The Research Design and Methodology}

\subsection{Research design/Type}

This research is a practical problem developed from the observation of asphalt road construction projects and the research questions are oriented to investigate the cause of time overrun in road construction projects of Addis Ababa city administration.

This research can be categorized as applied and descriptive type. It is applied because the research is initiated from practical problems and finds whether there exists time overrun or not. It is also descriptive because it tried to describe the actual rate of time overrun and the variables or factors of time overrun in Addis Ababa city administration.

\subsection{Sampling Design}

\subsubsection{Target Population}

The population of the study comprises the stake holders of road construction projects such as owners (city road authority administration), contractors and consultants who were involved in the construction process of road construction projects taken (considered) for the study (completed from 2000-2005E.c) under Addis Ababa city road authority to get possible reasons for time overrun. The questionnaire was distributed for engineers who are working under the contract management departments of the above mentioned stakeholders.

\subsubsection{Sampling Method}

Purposive sampling technique was used to select the respondents under owners, consultants and contractors. According to Walliman (2005), purposive sampling is a useful sampling method which allows a researcher to get information from a sample of the population that one thinks knows most about the subject matter.

\subsubsection{Unit of analysis}

The unit of analysis is the major entity that is being analyzed in a study. It is the 'what' or 'who' that is being studied. In terms of unit of analysis, this research focuses only on Asphalt road construction projects under Addis Ababa city administration which was completed within the last six years (from 2000-2005 E.C).

\subsection{Source of Data}

Both primary and secondary data were used in relation to the topic under discussion.

\subsection{Research Instrument}

To gather concrete data, all relevant and available data/documents were assessed and analyzed. These are project completion reports to disclose the fact that whether asphalt road constructions are completed as per the agreement/plan or not.

Contractors, owners and consultants have been approached for their view on causes of delay for road construction projects by using closed ended questionnaires (in the form of likert scale).

\subsection{Analysis and Finding Methods}

The analysis part combined (is based on) all groups of respondents (contractors, consultants and owners) in order to obtain significant results. The data is analyzed by calculating the relative important index model to rank the hypothesized factors based on their importance and frequency which is derived from the views of the respondents of the three groups. The spearman rank correlation coefficient is used to test the hypothesis of this research (whether there is significant agreement between the views of respondents from different groups to rank the delay factors).

\section{Results and Discussion}

\subsection{Introduction}

This chapter deals with the presentation of the data collected through questionnaire and document review. An attempt was made to collect relevant data from contract administration departments of owners, consultants and contractors of road construction projects which was completed within 2000-2005e.c, under Addis Ababa city road authority (AACRA).

\section{Volume 5 Issue 7, July 2016




\section{International Journal of Science and Research (IJSR) \\ ISSN (Online): 2319-7064}

Index Copernicus Value (2013): 6.14 | Impact Factor (2015): 6.391

Documents of the company essentially the completion reports of the road projects which are considered for this study was reviewed and presented here in this chapter.

\subsection{Yearly Accomplishment of Asphalt Road Construction Projects}

This section presents the yearly performances of the office in terms of comparing what was planned and achieved.

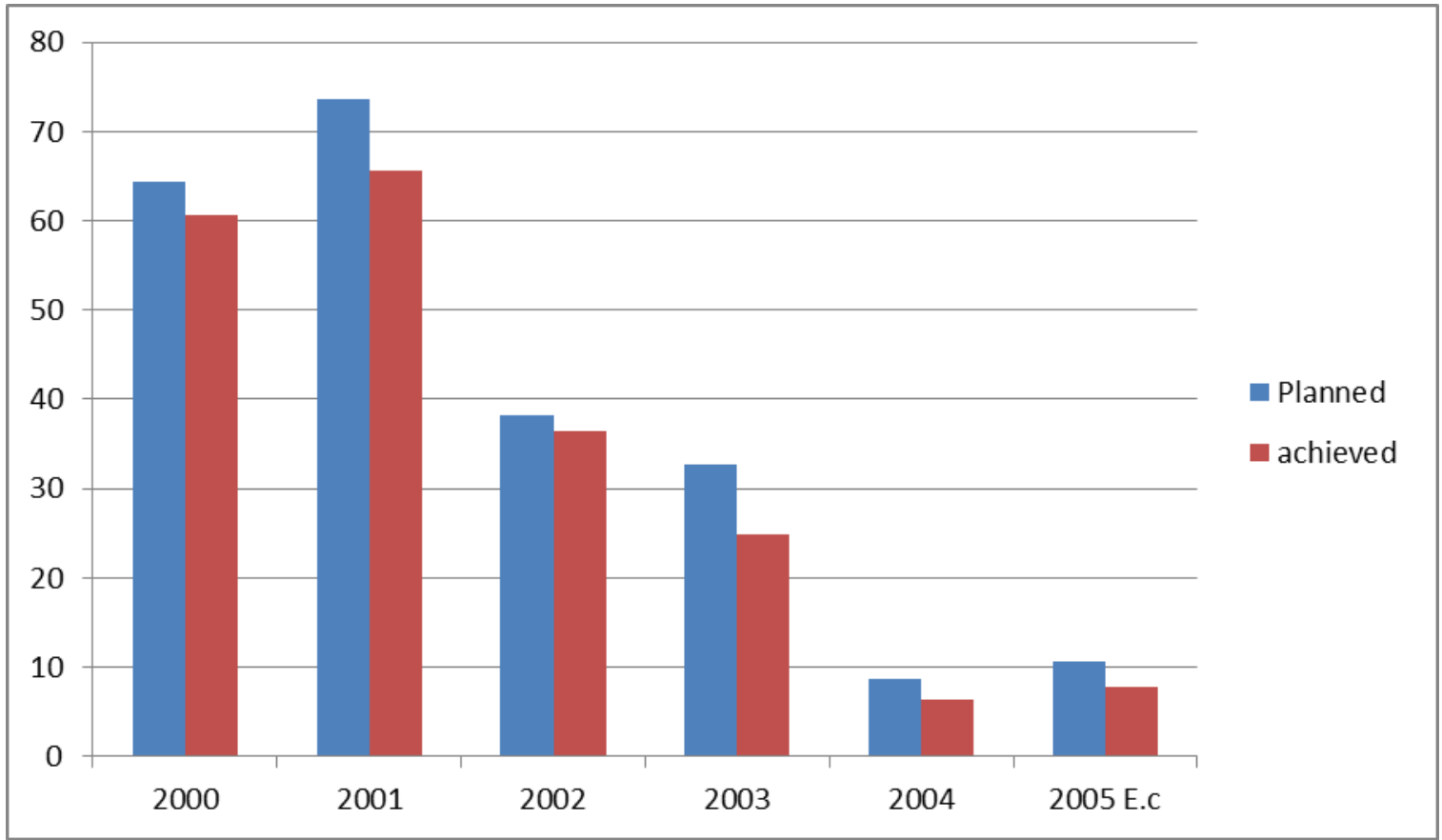

Figure 4.2: Yearly accomplishment of asphalt road construction projects from 2000 to 2005E.c in Kilo meters by Addis

\section{Source: AACRA information desk}

Ababa city road authority.

As we can understand from the above chart, Addis Ababa city road authority was short of achieving what was planned in all calendar years stated above. The numbers are representing kilometers of roads planned and accomplished in each year. There is a big difference between what was planned and accomplished during those years.

\subsection{Performance of Asphalt Road Construction Projects}

2000-2005 was the period when many road projects were completed which was commenced following the plan developed by the city administration to boom the road construction projects of Addis Ababa city administration.

Table 3.1: AACRA, completion report for road construction projects completed in 2000-2005e.c.

\begin{tabular}{|c|c|c|c|c|c|c|c|c|}
\hline No & Name of the project & $\begin{array}{c}\text { Date of } \\
\text { commencement }\end{array}$ & $\begin{array}{l}\text { Planed } \\
\text { completion } \\
\text { period }\end{array}$ & $\begin{array}{c}\text { Actual } \\
\text { completion } \\
\text { period }\end{array}$ & Contractor & Consultant & Planed cost & Actual cost \\
\hline 1 & $\begin{array}{l}\text { Winget squere- Asko } \\
\text { bridge }\end{array}$ & Dec-210G.c & Jul-2012G.c & Mar-2013G.c & $\begin{array}{l}\text { Tidhar } \\
\text { constr. }\end{array}$ & Yuniken & $207,498,019$ & $306,751,511$ \\
\hline 2 & $\begin{array}{c}\text { Ayat squire-Bole } \\
\text { Ayat village }\end{array}$ & Ap-2012 & Ap-2013 & Mar-2013 & $\begin{array}{c}\text { C.R,B.C } \\
\text { Addis } \\
\text { engineering }\end{array}$ & $\begin{array}{c}\text { Best } \\
\text { consulting }\end{array}$ & $150,032,280$ & $173,934,076$ \\
\hline 3 & $\begin{array}{l}\text { Winget squere - } \\
\text { Gojam ber }\end{array}$ & May-2006 & Jun-2008 & Dec-2012 & $\begin{array}{c}\text { C.R,B.C } \\
\text { Addis } \\
\text { engineering }\end{array}$ & Yuniken & $326,506,025$ & $728,864,968$ \\
\hline 4 & $\begin{array}{c}\text { Yerer ber- Fisash } \\
\text { mataria }\end{array}$ & Mar-2006 & Mar-2007 & Ap-2012 & $\begin{array}{l}\text { Medroc } \\
\text { constr. }\end{array}$ & $\begin{array}{c}\text { Zewde } \\
\text { Eskindir }\end{array}$ & $77,537,233$ & $90,820,184$ \\
\hline 5 & $\begin{array}{c}\text { Alem bank-yeshi } \\
\text { debele road }\end{array}$ & Jul-2008 & Sep-2009 & Mar-2012 & Enyi constr. & Hek amakari & $177,785,402$ & $198,698,122$ \\
\hline 6 & $\begin{array}{l}\text { Lideta reconstruction } \\
\text { road constr. }\end{array}$ & Oct-2011 & Mar-2012 & Aug-2012 & Enyi constr. & $\begin{array}{c}\text { Beza } \\
\text { consulting }\end{array}$ & $52,077,583$ & $52,077,583$ \\
\hline 7 & $\begin{array}{c}\text { Yerer ber ambesa } \\
\text { garage -Lem hotel, } \\
\text { Shola gebeya }\end{array}$ & Jul-2007 & Aug-2009 & May-2011 & Enyi constr. & $\begin{array}{c}\text { Best } \\
\text { consulting }\end{array}$ & $109,512,768$ & $132,262,895$ \\
\hline 8 & $\begin{array}{c}\text { Mekanisa-Jemo- } \\
\text { Sebeta }\end{array}$ & Jul-2007 & Ap-2009 & Jan-2011 & Hek Amakari & $\begin{array}{c}\text { Hek } \\
\text { Amakari }\end{array}$ & $115,539,588$ & $139,395,415$ \\
\hline 9 & $\begin{array}{c}\text { Gofa camp- Mekanisa } \\
\text { ring road }\end{array}$ & May-2006 & Jun-2009 & Oct-2010 & Enyi constr. & $\begin{array}{c}\text { Hek } \\
\text { Amakari }\end{array}$ & $43,576,867$ & $61,385,047$ \\
\hline
\end{tabular}


International Journal of Science and Research (IJSR)

ISSN (Online): 2319-7064

Index Copernicus Value (2013): 6.14 | Impact Factor (2015): 6.391

\begin{tabular}{|c|c|c|c|c|c|c|c|c|}
\hline 10 & $\begin{array}{l}\text { Megenagna- English } \\
\text { embasy-qebena 4kilo }\end{array}$ & May-2006 & Dec-2008 & App-2010 & $\begin{array}{c}\text { C.R,BC } \\
\text { Addis } \\
\text { engineering }\end{array}$ & $\begin{array}{c}\text { Beza } \\
\text { consulting }\end{array}$ & $146,890,588$ & $235,8880,038$ \\
\hline 11 & $\begin{array}{l}\text { Coca cola mazoria- } \\
\text { through abnet } \\
\text { teklehymanot square }\end{array}$ & Jul-2007 & May-2010 & May-2010 & $\begin{array}{c}\text { C.R,BC } \\
\text { Addis } \\
\text { engineering }\end{array}$ & $\begin{array}{l}\text { Zewde } \\
\text { Eskindir }\end{array}$ & $93,257,398$ & $113,076,890$ \\
\hline 12 & $\begin{array}{c}\text { Yeshi debele- Ambo } \\
\text { menged }\end{array}$ & Mar-2006 & May-2007 & Jun-2009 & $\begin{array}{l}\text { Medroc } \\
\text { constr. }\end{array}$ & $\begin{array}{l}\text { Zewde } \\
\text { Eskindir }\end{array}$ & $87,384,461$ & 103,841783 \\
\hline 13 & Meri radio -Beken & Mar-2006 & Mar-2007 & July-2009 & $\begin{array}{l}\text { Medroc } \\
\text { constr. }\end{array}$ & $\begin{array}{l}\text { Zewde } \\
\text { Eskindir }\end{array}$ & $50,365,079$ & $74,225,454$ \\
\hline 14 & $\begin{array}{c}\text { Mexico squire- } \\
\text { pushkin squire- } \\
\text { Mekanisa ring road }\end{array}$ & Jul-2007 & Nov-2009 & Nov-2009 & $\begin{array}{c}\text { C.R,BC } \\
\text { Addis } \\
\text { engineering }\end{array}$ & $\begin{array}{l}\text { Zewde } \\
\text { Eskindir }\end{array}$ & $147,678,225$ & 170,696594 \\
\hline 15 & $\begin{array}{l}\text { Yekatit } 12 \text { squire- } \\
\text { afincho ber-semen } \\
\text { hotel }\end{array}$ & Jul-2006 & Dec-2009 & Dec-2009 & $\begin{array}{c}\text { C.R,BC } \\
\text { Addis } \\
\text { engineering }\end{array}$ & $\begin{array}{l}\text { Highway } \\
\text { Amakari }\end{array}$ & $36,213,579$ & 63,093783 \\
\hline 16 & $\begin{array}{l}\text { Dama hotel-hana } \\
\text { Mariam bridge }\end{array}$ & May-2006 & May-2007 & Jun-2009 & Enyi constr. & $\begin{array}{l}\text { Zewde } \\
\text { Eskindir }\end{array}$ & $62,346,103$ & $75,361,614$ \\
\hline
\end{tabular}

\section{Source: AACRA, planning and budget office.}

As we can understand from the above table, almost $80 \%$ of the projects were completed beyond their planned completion period. It is possible to assume different causes/factors for the inefficiency of the above projects in terms of their time and cost requirement. The researcher assumed/hypothesized different factors which can contribute essentially for time overrun on road construction projects as it is presented above and prepared it with a likert scale questionnaire format to distribute to the respondents.

The results of this study are presented and discussed in three different categories in a way which enables to understand the views of contractors, consultants and owner about the causes of time overrun on road construction projects in Addis Ababa city administration.

\subsection{Factors Contributing for Time Overrun on Asphalt Road Construction Projects in AACRA}

This part of the paper consists of results and discussion of factors that contribute for time overrun (delay) in asphalt road construction projects.

\subsubsection{Ten Common Factors Contributing for Time Overrun from Owners View.}

Table 3.2: Factors contributing for time overrun on road construction projects in AACRA

\begin{tabular}{|c|c|c|c|c|c|c|c|c|}
\hline & \multicolumn{5}{|c|}{ Significance/frequency } & \multirow[t]{2}{*}{ Total value } & \multirow[t]{2}{*}{ RII } & \multirow[t]{2}{*}{ Rank } \\
\hline Hypothesized factors & 1 & 2 & 3 & 4 & 5 & & & \\
\hline slow cite clearance & 0 & 0 & 0 & 2 & 7 & 43 & 0.955 & 1 \\
\hline contractors financial problems & 0 & 0 & 0 & 4 & 5 & 41 & 0.911 & 2 \\
\hline Inflation & 0 & 0 & 0 & 4 & 5 & 41 & 0.911 & 3 \\
\hline exchange rate fluctuation & 0 & 0 & 0 & 5 & 4 & 40 & 0.888 & 4 \\
\hline supply of material & 0 & 0 & 3 & 6 & 0 & 33 & 0.733 & 5 \\
\hline inadequate contractors experience & 0 & 0 & 4 & 5 & 0 & 32 & 0.711 & 6 \\
\hline low productivity of labor & 0 & 0 & 5 & 3 & 1 & 32 & 0.711 & 7 \\
\hline inaccurate cost estimation & 0 & 0 & 5 & 4 & 0 & 31 & 0.688 & 8 \\
\hline poor resource management & 0 & 0 & 7 & 1 & 1 & 30 & 0.666 & 9 \\
\hline improper planning & 0 & 0 & 7 & 2 & 0 & 29 & 0.644 & 10 \\
\hline
\end{tabular}

\section{Sources: field survey, 2014.}

Therefore as we can understand from the views of owners, delay is a major problem which is commonly happening in the case of AACRA. According to these respondents, there are different factors to contribute for delay (time overrun) in the above case study and the factors are different in terms of their importance and frequency to happen.

3.4.2. Ten Common Factors Contributing for Time Overrun from Contractors View. 


\section{International Journal of Science and Research (IJSR) \\ ISSN (Online): 2319-7064}

Index Copernicus Value (2013): 6.14 | Impact Factor (2015): 6.391

Table 3.3: factors contributing for time overrun on road construction projects in AACRA

\begin{tabular}{|c|c|c|c|c|c|c|c|c|}
\hline & \multicolumn{5}{|c|}{ Significance/frequency } & \multirow[t]{2}{*}{ Total value } & \multirow[t]{2}{*}{ RII } & \multirow[t]{2}{*}{ Rank } \\
\hline Hypothesized factors & 1 & 2 & 3 & 4 & 5 & & & \\
\hline progress payments delay by owner & 1 & 2 & 3 & 4 & & 94 & 0.94 & 1 \\
\hline inaccurate cost estimation & 0 & 1 & 1 & 1 & & 94 & 0.94 & 2 \\
\hline supply of material & 0 & 0 & 1 & 4 & & 94 & 0.94 & 3 \\
\hline slow cite clearance & 0 & 0 & 1 & 4 & & 91 & 0.91 & 4 \\
\hline Inflation & 0 & 0 & 1 & 5 & & 88 & 0.88 & 5 \\
\hline slow equipment movement & 0 & 0 & 2 & 8 & & 88 & 0.88 & 6 \\
\hline exchange rate fluctuation & 0 & 0 & 2 & 8 & & 86 & 0.86 & 7 \\
\hline interference of owners & 0 & 0 & 2 & 10 & & 86 & 0.86 & 8 \\
\hline unforeseen cite conditions & 0 & 0 & 4 & 6 & & 84 & 0.84 & 9 \\
\hline quality of material & 0 & 1 & 4 & 5 & & 83 & 0.83 & 10 \\
\hline
\end{tabular}

Sources: field survey, 2014.

Therefore, like the views of owners we have summarized above, contractors argued that time overrun or delivering projects beyond the agreed time is a common and very serious problem which is affecting the performances of the owner (AACRA), contractors and consultants as it is difficult to accomplish tasks as planned.

3.4.3. Ten Common Factors Contributing for Time Overrun from Consultants View.

Table 3.4: Factors contributing for time overrun on road construction projects in AACRA

\section{Sources: field survey, 2014.}

\begin{tabular}{|l|l|l|l|l|l|l|l|l|l|}
\hline & \multicolumn{6}{|c|}{ Significance/frequency } & Total value & RII & Rank \\
\hline Hypothesized factors & 1 & 2 & 3 & 4 & 5 & & & \\
\hline progress payments delay by owner & 0 & 0 & 0 & 9 & 9 & 81 & 0.900 & 1 \\
\hline Inflation & 0 & 0 & 0 & 15 & 3 & 75 & 0.833 & 2 \\
\hline delay in commencement & 0 & 0 & 3 & 12 & 3 & 72 & 0.800 & 3 \\
\hline contractors financial problems & 0 & 0 & 3 & 12 & 3 & 72 & 0.800 & 4 \\
\hline unforeseen cite conditions & 0 & 0 & 2 & 15 & 1 & 71 & 0.788 & 5 \\
\hline inadequate contractors experience & 0 & 1 & 2 & 13 & 2 & 70 & 0.777 & 6 \\
\hline inaccurate cost estimation & 0 & 0 & 3 & 14 & 1 & 70 & 0.777 & 7 \\
\hline slow equipment movement & 0 & 0 & 3 & 15 & 0 & 69 & 0.766 & 8 \\
\hline incomplete drawings & 0 & 0 & 6 & 10 & 2 & 68 & 0.755 & 9 \\
\hline quality of material & 0 & 0 & 5 & 12 & 1 & 68 & 0.755 & 10 \\
\hline
\end{tabular}

consultants are keen on the commonness and recurrence of time overrun on asphalt road construction projects they are being involved and they are serious about the fact that what are the possible factors to contribute for the indispensability of this problem.

\subsection{Comparative Analysis}

This section of the study aims to see the level of agreement (significant relationship) between the three road construction parties; owner versus contractor, owner versus consultant and contractor versus consultant in terms of their view to rank the hypothesized factors which can contribute for time overrun on the understudied road construction projects. In this research the Spearman's correlation is used.

Table 3.5: Correlation test of the most important factors of time overrun among contractor, consultant and owner

\begin{tabular}{|c|c|c|l|c|}
\hline Respondents & $\begin{array}{c}\text { Correlation } \\
\text { coefficient } \\
\text { (Calculated } \\
\text { value of P) }\end{array}$ & $\begin{array}{c}\text { Critical } \\
\text { value of } \mathrm{P}\end{array}$ & $\begin{array}{l}\text { Significance } \\
\text { for } \mathrm{P}<0.05\end{array}$ & $\begin{array}{c}\text { Reject/don't } \\
\text { reject the } \\
\text { Null } \\
\text { Hypothesis }\end{array}$ \\
\hline $\begin{array}{c}\text { Owner and } \\
\text { Contractor }\end{array}$ & 0.247 & 0.441 & Insignificant & $\begin{array}{c}\text { Fail to } \\
\text { reject }\end{array}$ \\
\hline $\begin{array}{c}\text { Owner and } \\
\text { consultant }\end{array}$ & 0.414 & 0.441 & Insignificant & $\begin{array}{c}\text { Fail to } \\
\text { reject }\end{array}$ \\
\hline $\begin{array}{c}\text { Contractor } \\
\text { and } \\
\text { consultant }\end{array}$ & 0.649 & 0.441 & Significant & Reject \\
\hline
\end{tabular}

In this case, with a significance level of $95 \%(P=0.05)$, the calculated value of $\rho$ for the first two group cases are less than the critical values of $\rho$, so the hypothesis that there is no significant agreement between the respondents is failed to be rejected i.e. the null hypothesis is failed to be rejected. Meaning, there is no significant agreement between owner versus contractors and owner versus consultant in ranking factors contributing for time overrun in asphalt road construction projects in Addis Ababa city.

But for the last (third) group, the calculated value of $\rho$ is greater than the critical value of $\rho$, so, the hypothesis that there is no significant agreement between the respondents is rejected. That means, there is a significant agreement between contractors and consultants in ranking factors contributing for time overrun on asphalt road construction projects in Addis Ababa city. From Table 4.5, above, it can be concluded that there is no strong correlation between the attitudes of the owner respondents versus contractor respondents and owner respondents versus consultant respondents.

\section{Conclusions and Recommendations}

\subsection{Conclusions}

From the results of the analysis of secondary data and 


\section{International Journal of Science and Research (IJSR) \\ ISSN (Online): 2319-7064}

Index Copernicus Value (2013): 6.14 | Impact Factor (2015): 6.391

respondents' responses the following conclusions are drawn.

1) Almost $80 \%$ of the projects were completed beyond their planned completion period out of the asphalt road construction projects which was completed from 20002005Ec, Therefore the researcher concluded that, time overrun for asphalt road construction project in Addis Ababa city administration is common.

2) Causes of delay are related with both the owners, contractors, consultants and slightly with external factors.

3) It should be noted that owner, contractors, consultants and even the economy of the city and the country are all affected by the problem of untimely delivery of these projects.

4) There is no strong correlation on the responses of owner, contractor and consultant respondents, i.e. between owner versus contractors and owner versus consultants; but there is a strong correlation on the responses of contractor and consultant respondents.

\subsection{Recommendations}

Based on the findings of the research, the following recommendations are forwarded which is expected from key stakeholders of asphalt road construction projects in Addis Ababa city administration.

1) The owner should ensure that adequate funds are available before projects are started, so that contractors can be paid in accordance with the contract agreement which will enhance the timely delivery of road projects.

2) Owner should allow sufficient time to prepare project briefs and other feasibility studies as it will reduce the contribution of inaccurate cost estimation, unforeseen cite conditions and slow cite clearances for the untimely delivery (time overrun) of asphalt road construction projects. .

3) Contractors should ensure efficient time management through proper resource planning, duration estimation, and schedule development and control; to avoid delay.

4) Commence projects on time according to the agreement.

5) Contractors are advised to set up stores for the necessary construction materials, and especially for scarce or that are in limited quantity in the markets to avoid time overrun.

6) Contractors are recommended to correctly forecast the possible exchange rate fluctuation and the overall economic trends of the country.

7) All the specifications, criteria's and requirements must be clear and easily communicable for contractors and other participants.

8) Consultants are recommended to make a very detail analysis in the design and drawing stage to reduce or even to avoid all the uncertainties which the construction participants would face once the construction work is commenced. .

9) A flexible design should be prepared which is possible to respond more proactively to necessary changes in owner needs and requirements.

10) The researcher recommends consultants to develop a clear and complete project scope to avoid frequent changes.

11) The government should try to stabilize the variations in inflation and foreign currency related issues as it can reduce uncertainties in terms of the required cost and consequently time of delivering projects through changing the monetary policies of the country to stabilize all these things.

12) The researcher also would like to mention one thing which is expected from the government; installing active transportation system to reduce the impacts of poor supply of materials.

\section{References}

[1] A.A. Aibinu*, G.O. Jagboro, (2002), The effects of construction delays on project delivery in Nigerian construction industry, International Journal of Project Management p 593-599

[2] Abbas, M.I. (2006) causes and effects of delays in Aceh construction industry, master's thesis, university technology

[3] Agaba, E. (2009) Poor Planning Delaying Government Projects (Business News Pullout), The New Vision, Vol. 24, pp 6

[4] Aibinu, A.A., and Jagboro, G., O. 2002. The effects of construction delays on project delivery in Nigerian construction industry, International Journal of Project Management, Vol. 20, pp. 593-9.

[5] Al-Momani, A. (2000). Construction delay: a quantitative analysis. Int. J. Project Management, 5159.

[6] Asnaashari, E., Farahani, S., Hoseini, A., and Knight, A. (2009). Causes of delay in Iranian construction projects. Fifth International Conference on Construction in the 21st Centur y (CITC-V) "Collaboration and Integration in Engineering, Management and Technolog y" Istanbul, Turkey.

[7] Baldwin, J., and Manthei, J. (1971). "Causes of delay in the construction industry." J. Constr. Div. p, 177187.

[8] Chan DWM, Kumaraswamy MM. (1997). A comparative study of causes of time overruns in construction project. Hong Kong. Int. J. project manage. 15 (1): 55-63.

[9] Chileshe, N., and Berko, P. D. 2010. Causes of project cost overrun within Ghanian road construction sector. In the proceeding of ASOCSA $5^{\text {th }}$ Built Environment Conference, Durban South Africa.

[10] El-Razek, M.E.A. Bassoioni, H.A \& Mobarak, A.M. (2008). Causes of Delay in building Construction Projects in Egypt, Journal of Construction Engineering and Management, Vol 134, Issue 11, p 831

[11] Faridi, A. and El-sayegh, s.(2006), significant factors causing delay in the UAE construction industry.J. construction management and economics.

[12] Fetene Nega, (2008), couses and effects of cost overrun on public building constrauction projects in Ethiopia, fulfillment of masters thesis

[13] Haseeb, M., Xinhai-Lu, Aneesa Bibi, A., Maloof-udDyian, Rabbani, W. (2011). Problems of projects and effects of delays in the construction industry of Pakistan. Australian Journal of Business and Management Research, 1 (5) pp 41-50.

[14] www.qsspace.qu.edu.qa/handle/10576/7921 Accessed $7 / 3 / 2014$ 


\section{International Journal of Science and Research (IJSR) \\ ISSN (Online): 2319-7064}

Index Copernicus Value (2013): 6.14 | Impact Factor (2015): 6.391

[15] Ibrahim Mahamid, (2013), Frequency of time overrun causes in road construction in Palestine: Contractors' View, Construction Engineering and Management, Hail University Civil Engineering Department Hail, Saudi Arabia imahamid@ymail.com

[16] Kombo, D.,K., and Tromp, D.A. 2006. Proposal and thesis writing; an introduction; $2^{\text {nd }}$ reprint; Pauline Publication Africa;Kenya. www.wagner.nyu.edu/.../whatisresearch.php Accessed 5/3/2014.

[17] Kometa, S. T., Olomolaiye, P. O., and Harris, F. C. (1994). "Attributes of UK construction clients influencing project consultants' performance." Constr. Manage. Econ., 12(5), 433-443.

[18] M. Haseeb , Xinhai-Lu, Aneesa Bibi, Maloof-udDyian, Wahab Rabbani, (2011), Causes and Effects of Delays in Large Construction Projects of Pakistan, Kuwait Chapter of Arabian Journal of Business and Management Review Vol. 1,

[19] Mahamid, I. and Bruland, A.(2012), cost deviation in conmstruction projects. The case of Palestine. Australasian journal of construction economics and building vol.12

[20] Odeh, A. and Battaineh, H. (2002). Factors of construction delay: traditional contracts. Int. J. Project Manage. 20(1): 67-73.

[21] Pickavance, K. 2005. Delay and disruption in construction contracts, 3rd edition. Informa Legal Publishing UK

[22] PMBOK ${ }^{\circledR}$ Guide, (2008), a guide to the project management body of knowledge, Project Management Institute, Inc. 14 Campus Boulevard Newtown Square, Pennsylvania 19073-3299 USA

[23] Puspasari, T. R. (2006). "Factors causing the poor performance of construc- tion project." Master's Thesis, Univ. of Technology Malaysia, Johor Bahru, Malaysia. University, P. O. Box 7062, Kampala

[24] Sadi A. Assaf *, Sadiq Al-Hejji, (2006), Causes of delay in large construction projects, International Journal of Project Management 349-357 